\title{
Modelowanie ścieżki produkcji FAME z alg pod kątem gospodarki o obiegu zamkniętym
}

\section{Modeling of algal FAME production pathway in the context of circular economy}

\author{
Delfina Rogowska \\ Instytut Nafty i Gazu - Państwowy Instytut Badawczy
}

\begin{abstract}
STRESZCZENIE: Artykuł przedstawia problematykę zarządzania strumieniami masy i energii przepływającymi przez podmioty występujące w łańcuchu dostaw FAME z alg w kontekście wdrożenia idei circular economy. W artykule dokonano krótkiego przeglądu literaturowego dotyczącego budowy modelu gospodarki o obiegu zamkniętym. Z przeglądu tego wynika, że punktem wyjścia do zdefiniowania takiego modelu są modele biznesowe lub modele opisujące zachowania podmiotów w łańcuchu wartości danego produktu. Literatura wskazuje, że wciąż poszukiwane są odpowiednie modele matematyczne opisujące gospodarkę o obiegu zamkniętym. Integracja takiego modelu z modelem uwzględniającym cele środowiskowe jest zagadnieniem nowym i stanowi wyzwanie. Wymaga ona szerszego spojrzenia na relacje biznesowe - nie tylko z punktu widzenia zysku przedsiębiorstwa, ale również osiagniętych wartości środowiskowych i społecznych. I właśnie włączenie parametrów mierzalnych w innych wartościach niż ekonomiczne lub niemierzalnych wymaga nowego podejścia do modelowania. Do tego konieczne jest zdefiniowanie tych wartości środowiskowych w kontekście całego systemu obliczeniowego. W niniejszym artykule przedstawiono model produkcji FAME z alg zgodnie z wytycznymi budowy modelu gospodarki o obiegu zamkniętym podanymi w literaturze. Dla modelu zidentyfikowano głównych uczestników, granice systemu obliczeniowego, opisano przepływy strumieni masy i energii pomiędzy jednostkami. Granice systemu obliczeniowego objęły nie tylko podmioty występujące w łańcuchu dostaw, ale także przedsiębiorców dostarczających i odbierających surowce i produkty. Tym samym podmioty takie jak np. elektrociepłownia, producent pasz, producent nawozów stały się elementem systemu obliczeniowego. Emisja GHG (czy inne oceniane oddziaływania środowiskowe) generowana przez te podmioty również jest uwzględniana w obliczeniach dla całego układu. Sporządzono także tabele inwentarzowe. W artykule przedstawiono algorytm budowy takiego modelu. Optymalizacja modelu polega na takim dobraniu przepływu strumieni pomiędzy poszczególnymi przedsiębiorcami, aby osiągnąć efekt założony dla całego układu (np. minimalizacja emisji GHG), a nie dla pojedynczego przedsiębiorstwa czy produktu.
\end{abstract}

Słowa kluczowe: biopaliwa, algi, gospodarka o obiegu zamkniętym, modelowanie.

ABSTRACT: The article presents the issues of managing mass and energy streams flowing throughout entities being part of algal FAME chain of custody, in the context of the circular economy idea. The article presents a brief literature review concerning the modeling of circular economy. Findings from the literature review indicate that the starting point is business models or models describing the behavior of entities occurring in the value chain of a given product. The literature indicates that an adequate model describing circular economy is still being searched for. Integration of such a model with an environmental-oriented model is quite a new issue and it poses a challenge. It requires a much wider view on business relations, not only from the point of view of profit but also the attained environmental and social values. Thus, including parameters measurable in values other then economic or non-mesurable parameters requires a new modeling approach. For this purpose, a definition of such values is needed. The article presents an algal FAME production model in accordance with the guidelines for creating a circular economy business model. The main players and system boundaries were identified, and the flows of mass streams and energy among installations were described for the model. The system boundaries covered not only entities occurring along the supply chain but also entrepreneurs supplying feedstock and receiving products. GHG emission (or other assessed environmental impacts) generated by these entities is included in the calculation made for the whole system. An inventory table was also drawn up. The article presents the algorithm of building such a model. The optimization of such a model is based on selecting stream flows between particular economic operators in such way to achieve an effect assumed for a whole system (e.g. minimization of GHG emission) but not for a single economic operator or product.

Key words: biofuels, algae, circular economy, modeling.

Autor do korespondencji: D. Rogowska, e-mail: delfina.rogowska@inig.pl

Artykuł nadesłano do Redakcji 2.01.2019 r. Zatwierdzono do druku 22.07.2019 r. 


\section{Wstęp}

Kierunki rozwoju technologii, w tym przerobu surowców - biopaliw/biokomponentów, są dziś determinowane nie tylko osiągnięciami w dziedzinie systemów zasilania i samych silników samochodowych, ale głównie polityką państwa czy wspólnot państw dotyczącą bezpieczeństwa energetycznego i ochrony środowiska. Warto w tym miejscu zaznaczyć, że polityka w zakresie promowania odnawialnych źródeł energii prowadzona jest nie tylko w Unii Europejskiej, ale również w innych krajach naszego globu, np. Stanach Zjednoczonych Ameryki Północnej czy Chinach. W Europie najistotniejsze w tym zakresie są: tzw. dyrektywa RED (dyrektywa 2009/28/WE), tzw. dyrektywa ILUC (dyrektywa 2015/1513) oraz procedowana właśnie dyrektywa zwana RED II, która definiuje politykę biopaliwową w Europie w latach 2021-2030 (European Parliament legislative resolution of 13 November 2018).

Dyrektywa RED założyła udział energii ze źródeł odnawialnych $\mathrm{w}$ transporcie na poziomie $10 \% \mathrm{w}$ roku 2020. Mając na uwadze, że tak wysokie zapotrzebowanie na biopaliwa może sprawić, że uprawa surowców do ich produkcji będzie miała negatywny wpływ na środowisko, wprowadzono kryteria zrównoważonego rozwoju. W czasie obowiązywania dyrektywy zebrane zostały doświadczenia z rynku, a wnioski z analizy wprowadzono w życie dyrektywą ILUC. Dyrektywa ta zmieniła priorytety w obszarze biopaliw, wskazując na konieczność stopniowej redukcji ilości biopaliw produkowanych z surowców rolnych, kładąc nacisk na zwiększenie ilości biopaliw produkowanych z surowców nieżywnościowych, w tym głównie odpadów i pozostałości. Idea ta jest wyrażona poprzez ustanowienie celu dla biopaliw zaawansowanych oraz rozliczanie ich wkładu w udział energetyczny podwójnie. Biopaliwa zaawansowane są to biopaliwa wytworzone z surowców wymienionych w załączniku IX do dyrektywy ILUC, niezależnie od technologii ich przetwarzania, którymi są:

- algi, jeżeli są hodowane na lądzie, w stawach lub w fotobioreaktorach;

- frakcja biomasy zmieszanych odpadów komunalnych, ale nie segregowanych odpadów z gospodarstw domowych, z zastrzeżeniem celów recyklingu na mocy art. 11 ust. 2 lit. a) dyrektywy 2008/98/WE;

- bioodpady, zgodnie z definicją w art. 3 pkt 4 dyrektywy 2008/98/WE, z gospodarstw domowych podlegające selektywnej zbiórce zgodnie z definicją w art. 3 pkt 11 tej dyrektywy;

- frakcja biomasy odpadów przemysłowych nienadająca się do wykorzystania w łańcuchu żywnościowym ludzi i zwierząt, w tym materiał z detalu i hurtu oraz z przemysłu rolno-spożywczego, rybołówstwa i akwakultury, z wyłączeniem surowców wymienionych w części B załącznika;
- słoma;

- obornik i osad ściekowy (ścieki z zakładów wytłaczania oleju palmowego i puste wiązki owoców palmy);

- olej talowy;

- surowa gliceryna;

- wytłoczyny z trzciny cukrowej;

- wytłoki z winogron i osad winny z drożdży;

- łupiny orzechów;

- łuski nasion;

- kolby oczyszczone z ziaren kukurydzy;

- frakcja biomasy odpadów i pozostałości z leśnictwa i gałęzi przemysłu opartych na leśnictwie, np. kora, gałęzie, trzebież, liście, igły, wierzchołki drzew, trociny, strużyny, ług czarny, osad włóknisty, lignina i olej talowy;

- inny niespożywczy materiał celulozowy, określony w art. 2 ust. 2 lit. s);

- inny materiał lignocelulozowy, określony w art. 2 ust. 2 lit. r), z wyjątkiem kłód tartacznych i kłód skrawanych;

- odnawialne ciekłe lub gazowe paliwa transportowe pochodzenia niebiologicznego;

- wychwytywanie i wykorzystanie dwutlenku węgla na potrzeby transportu, jeżeli źródło energii jest odnawialne zgodnie z art. 2 akapit drugi lit. a);

- bakterie, jeżeli źródło energii jest odnawialne zgodnie $\mathrm{z}$ art. 2 akapit drugi lit. a);

oraz

- zużyty olej kuchenny;

- tłuszcze zwierzęce sklasyfikowane w kategoriach 1 i 2 w myśl rozporządzenia Parlamentu Europejskiego i Rady (WE) nr 1069/2009.

Analiza przedstawionych powyżej surowców wskazuje, że jedynie zużyty olej kuchenny i olej z alg są surowcami możliwymi do wykorzystania w istniejących instalacjach produkujących biopaliwa. Zgodnie z dyrektywą RED II, ze względu na duże ryzyko nadużyć, olej kuchenny ma być surowcem ograniczanym. Produkcja biodiesla na konwencjonalnych instalacjach to proces wysokoemisyjny, w którym znaczący udział emisji GHG w cyklu życia przypisany jest etapowi uprawy rzepaku (Berdechowski, 2017). Dlatego należy się spodziewać, że w kolejnej dekadzie olej z alg będzie nabierał znaczenia. Jednak technologie przetwarzania alg nie są jeszcze na tyle wydajne i rozwinięte, aby dostarczyć wystarczające ilości surowca dla przemysłu biopaliwowego. Olej z alg jest również postrzegany jak perspektywiczny w krajach, które ustanowiły cele biopaliwowe (np. Pakistan: 10\% w roku 2020), a których możliwości uprawy surowców rolniczych do produkcji biopaliw, ze względu na uwarunkowania klimatyczne i środowiskowe, są ograniczone (Hasnain et al., 2018).

Równolegle do prac nad poprawą zrównoważonego charakteru biopaliw rozpoczęto w Europie prace na wdrożeniem idei 
circular economy (CE) do ustawodawstwa Unii Europejskiej (Bourguignon, 2014). Na wstępie należy zauważyć, że można spotkać różne tłumaczenia zwrotu circular economy, takie jak gospodarka bezodpadowa, gospodarka okrężna, gospodarka o obiegu zamkniętym i inne. Zwrot ten nie jest jednoznaczny ani z ideą biogospodarki, ani z ogólnie pojętym zrównoważonym rozwojem (Manninen et al., 2018).

W lipcu 2014 roku Komisja Europejska wydała komunikat (komunikat COM/2014/0398) wskazujący na potrzebę wprowadzenia w Europie gospodarki o obiegu zamkniętym. Systemy takiej gospodarki pozwalają zachować możliwie jak najdłużej wartość dodaną produktów i wyeliminować odpady. Produkty nie są utylizowane czy składowane, kiedy ich cykl życia dobiega końca, tylko są kierowane ponownie do wykorzystania w sposób produktywny i tworzą w ten sposób kolejną wartość obiegu. Taka transformacja gospodarki wymaga zmian w każdym ogniwie łańcucha wartości, począwszy od fazy projektowania produktu do nowych modeli biznesowych i rynkowych. Konieczne jest również wprowadzenie zmian sposobów przekształcania odpadów tak, aby powstały $\mathrm{z}$ nich zasoby do powtórnego wykorzystania. Będzie się to także wiązało ze zmianą zachowań konsumentów. Taka reorganizacja systemu zarządzania zasobami wymusi zmiany technologiczne i tym samym wprowadzenie innowacji nie tylko w technologiach, ale również w organizacji, społeczeństwie, metodach finansowania i polityce.

Analiza dotycząca możliwości inkorporacji idei circular economy w przemyśle biopaliwowym została przedstawiona w pracy oraz publikacji autorki (Rogowska, 2017, 2018a).

Mając na uwadze obecną politykę UE dążącą do stworzenia gospodarki o obiegu zamkniętym, promocję surowców nieżywnościowych do produkcji biopaliw (w tym alg), konieczne będzie opracowanie modelu produkcji FAME z alg uwzględniającego założenia idei circular economy.

Naukowe podejście do zagadnienia jest problemem stosunkowo nowym. Według Galvao et al. (2018), którzy stworzyli bazę danych artykułów naukowych poświęconych tematyce gospodarki o obiegu zamkniętym, pierwsze publikacje pojawiły się w 2005 roku, ale większość dostępna jest od roku 2017. Co ciekawe, 30\% spośród 25 wybranych artykułów o najwyższym wskaźniku cytowań odnosiło się do badań prowadzonych w Chinach. Należy również zauważyć, że zmiana podejścia do gospodarki w kierunku budowy gospodarki o obiegu zamkniętym nie jest jedynie domeną Europy. USA mają krajowy plan w zakresie wdrażania biogospodarki, a generalnie ,zielona gospodarka” jest promowana przez Program Narodów Zjednoczonych ds. Środowiska (D’Amato et al., 2017).

Hodowla alg może być prowadzona według różnych ścieżek (otwarte stawy, bioreaktory, różne techniki osuszania alg i ekstrakcji oleju). Do dalszych rozważań przyjęto, że modelowa ścieżka produkcji biodiesla z alg prowadzona będzie w sztucznej hodowli z wykorzystaniem ścieków komunalnych. Model w sposób schematyczny przedstawiono na rysunku 1.

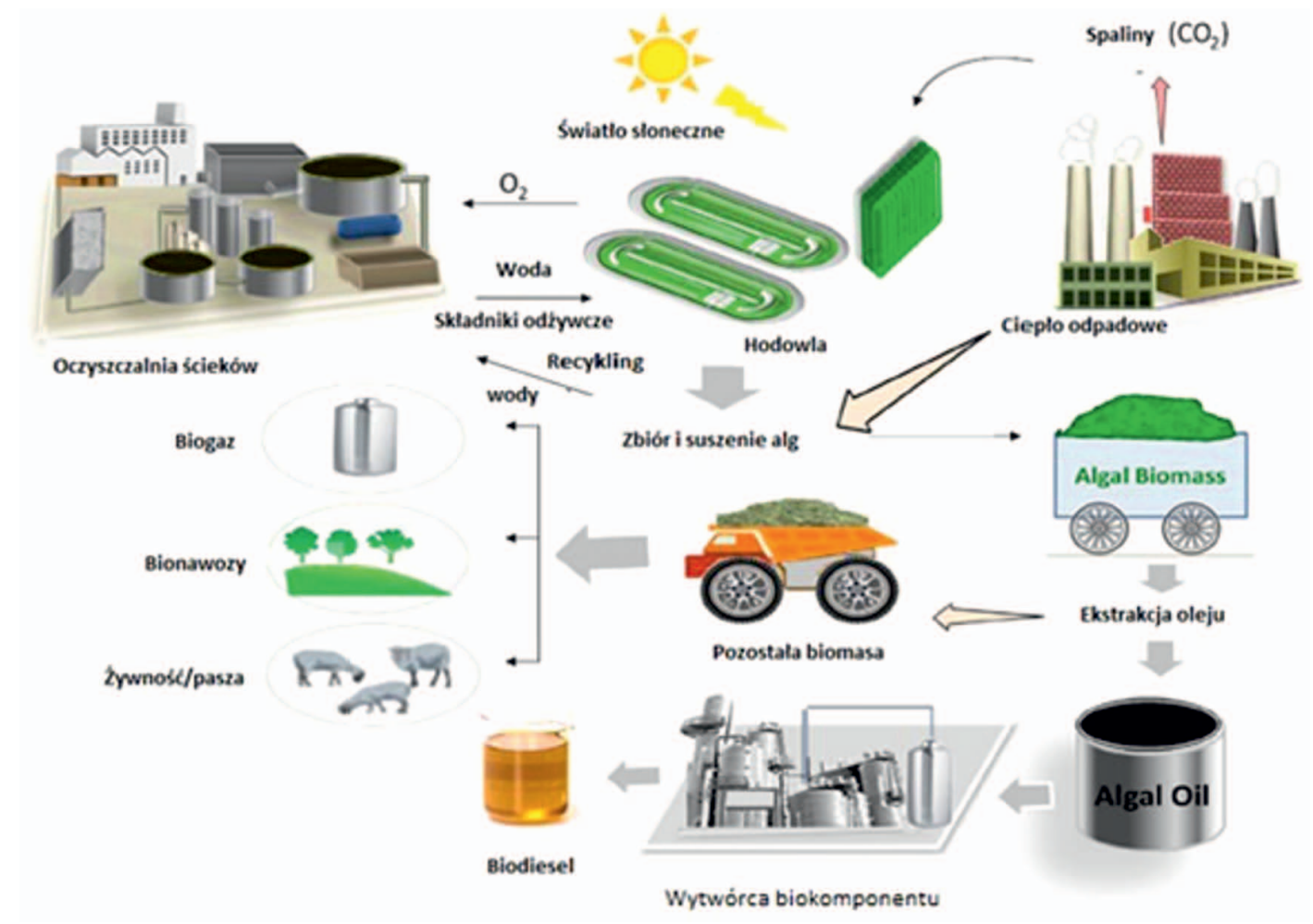

Rys. 1. Schemat modelowej ścieżki produkcji biodiesla z alg (Rastogi et al., 2018)

Fig. 1. Scheme of model of algae biodiesel production pathway (Rastogi et al., 2018)

\section{Opracowanie modelu matematycznego}

Budowa gospodarki o obiegu okrężnym nie powinna być celem samym w sobie, ale powinna przynieść pozytywny efekt, w szczególności środowiskowy, przy zachowaniu rentowności i zyskowności produkcji. Aby taki cel zrealizować, konieczne jest włączenie narzędzi matematycznych, w tym narzędzi do optymalizacji, co musi być poprzedzone zbudowaniem modelu matematycznego. 
Opisanie całej gospodarki, np. na poziomie danego kraju, modelem matematycznym jest bardzo dużym wyzwaniem. Dlatego naukowcy tworzą takie modele na niższym poziomie szczegółowości (circular business models, CBM). Pratap et al. w swojej publikacji (2018) przedstawili problem modelowania gospodarki o obiegu zamkniętym dla małych i średnich przedsiębiorstw. Model ten opiera się na teorii planowanego zachowania (theory of planned behavior) dla zbadania wewnętrznych i zewnętrznych czynników wspierających rozwój i dających wsparcie w implementacji circular economy wśród małych i średnich przedsiębiorstw. Jest to bardzo ważne i bardzo ciekawe zagadnienie, istotne dla powodzenia działania takiego modelu gospodarki, jednak aspekty behawioralne są niewystarczające z punktu widzenia budowy modelu gospodarki o obiegu zamkniętym, ponieważ nie obejmują wszystkich kwestii związanych z ochroną środowiska naturalnego czy ze zrównoważonym rozwojem.

Gospodarka o obiegu zamkniętym jest również opisywana modelami biznesowymi (Adeniyi et al., 2018; Geissdoerfer et al., 2018). Tu znaczącą rolę odgrywa koncepcja wymiany wartości utraconych (failed value exchanges). Zakłada ona, że realizowanie przez przedsiębiorstwa wartości, które są utracone, zniszczone lub nie są oferowane pomimo zapotrzebowania na rynku, może potencjalnie przynieść korzyści społeczeństwu, a jednocześnie pozwolić przedsiębiorstwu zyskać przewagę konkurencyjną. Tak więc modele te skupiają się głównie na zdefiniowaniu przepływów wartości (towarów, usług, przepływów pieniężnych), nie analizując kwestii wpływu na środowisko danego kierunku przepływu wartości. Modele te są zdefiniowane jako uproszczone reprezentacje elementów złożonego systemu organizacyjnego i wskazują wzajemne relacje między tymi elementami. Określają one propozycję wartości organizacji, tworzenie i dostarczanie wartości oraz przechwytywanie wartości i mają na celu analizę, planowanie i komunikację w obliczu rosnącej złożoności. Przy takich założeniach tworzone są biznesowe modele gospodarki o obiegu zamkniętym (circular business models, CBM). Największa różnica pomiędzy konwencjonalnym modelem biznesowym a tym zaprojektowanym dla gospodarki o obiegu zamkniętym występuje przy tworzeniu wartości, elementach dostawy, a szczególnie w łańcuchu dostaw. Tu szczególną rolę odgrywa zamknięcie obiegu surowców (Geissdoerfer et al., 2018). Według Boonsa i Lüdeke-Freunda (2013) zidentyfikowane zostały cztery elementy modelu biznesowego:

1) propozycja wartości: jaka wartość jest wbudowana w produkt/usługę oferowane przez firmę;

2) łańcuch dostaw (lub wartość): $w$ jaki sposób relacje $z$ dostawcami są zorganizowane i zarządzane;

3) interfejs klienta: $w$ jaki sposób relacje $z$ klientami są zorganizowane i zarządzane;
4) model finansowy: koszty i korzyści elementów wymienionych w pkt 1, 2 i 3 oraz ich podział na interesariuszy modeli biznesowych.

Jest to model ekonomiczny oparty na wartościach istotnych z punku widzenia rynkowego (zysk).

Dopiero publikacja Manninen et al. (2018) zwraca uwagę na konieczność połączenia aspektów modeli biznesowego, społecznych i środowiskowych. Wzrost efektywności wykorzystania zasobów, co stanowi między innymi cel CE, wymaga osiągnięcia lepszej równowagi pomiędzy gospodarką, środowiskiem i społeczeństwem. W wielu przypadkach weryfikacja korzyści środowiskowych modeli biznesowych CE nie jest prosta z powodu złożonych łańcuchów wartości, braku danych lub trudności w zdefiniowaniu systemu odniesienia dla oceny ulepszeń produktów środowiskowych. Ponadto dostępna norma (np. ISO 14040:2009 Zarządzanie środowiskowe - Ocena cyklu życia - Zasady i struktura) wymaga dostępu do danych dotyczących zasobów. Nawet gdy ocena cyklu życia jest zastosowana do kontekstu modelu biznesowego (Lindahl et al., 2014), ma te same wady, które pojawiają się przy ocenie LCA produktów, takie jak wykorzystanie średnich danych z baz danych i przyjmowanie założeń. Autorzy publikacji (Manninen et al., 2018) zwracają dalej uwagę, że aby stwierdzić, czy model gospodarki o obiegu zamkniętym jest przyjazny dla środowiska, należy postawić dwa pytania: 1. Czy przedsiębiorcy w ramach circular economy rzeczywiście mają pozytywny wpływ na środowisko, biorąc pod uwagę wszystkie działania w całym łańcuchu wartości?

2. W jaki sposób można zweryfikować wpływ na środowisko i wartościowe propozycje CBM?

W konwencjonalnym podejściu do biznesu miarą sukcesu jest zysk przedsiębiorstwa. W przypadku myślenia nakierunkowanego na zrównoważony rozwój takie podejście jest niewystarczające. Wymagane jest bowiem bardziej holistyczne spojrzenie na wartości, które integruje cele społeczne i środowiskowe z celami ekonomicznymi. Wartości opartej na kryteriach zrównoważonego rozwoju nie można stworzyć dla klientów bez tworzenia wartości dla szerszej grupy interesariuszy, ponieważ biznes jest, ,prowadzony” przez sieć interesariuszy. Pomimo tego, że model biznesowy jest podejściem rynkowym, firma, która przyczynia się do zrównoważonego rozwoju, musi tworzyć wartość dla całej gamy interesariuszy i środowiska naturalnego, a nie tylko dla klientów i akcjonariuszy (Manninen et al., 2018). I dalej według Manninen et al. (2018) koncepcja CE opiera się na trzech zasadach: zachowaniu i zwiększeniu kapitału naturalnego, optymalizacji zysków z wykorzystywanych zasobów i zwiększeniu efektywności systemu (minimalizacja negatywnych skutków zewnętrznych). Przedsiębiorstwa działające zgodnie z ideą circular economy powinny zastosować tę zasadę do swojego działania, po 
to aby przejść z biznesu liniowego na bardziej zamknięty. Według European Environment Agency (EEA, 2016) wyłonić można pięć głównych kategorii takiego działania:

1) mniejszy wkład i wykorzystanie zasobów naturalnych;

2) zwiększony udział zasobów odnawialnych i podlegających recyklingowi oraz energii;

3) zmniejszone emisje;

4) mniej strat materialnych/pozostałości;

5) utrzymywanie wartości produktów, komponentów i materiałów w gospodarce.

Aby model mógł być opisany i następnie rozwiązany, konieczne jest skwantyfikowanie powyższych kategorii i przyjęcie wymagań jakościowych.

Omawiana publikacja (Manninen et al., 2018) podaje algorytm tworzenia ram modelu CE. Algorytm ten przedstawiono na rysunku 2.

Problem opracowania modelu matematycznego obejmującego przepływy strumieni masy i energii pomiędzy różnymi gałęziami przemysłu został wstępnie w Polsce poruszony w pracy autorki (Rogowska, 2017) i opublikowany (Rogowska, 2018a). Według zacytowanych pozycji istotne jest:

- zdefiniowanie granic systemu obliczeniowego, a więc określenie, które elementy (instalacje, zakłady produkcyjne) wchodzą w skład systemu. W gospodarce o obiegu zamkniętym stanem idealnym będzie brak wejść oraz wyjść do/z układu;

- opracowanie bilansu masowego i energetycznego dla całego układu zamkniętego. Tu szczególnie istotna jest znajomość mechanizmów i reakcji fizykochemicznych zachodzących w poszczególnych ogniwach, np. w jaki sposób zmniejszenie ilości surowca podawanego do biogazowni (przy alternatywnym skierowaniu wywaru gorzelnianego jako nawozu) wpłynie na uzysk biogazu i tym samym produkcję energii elektrycznej i cieplnej;

- opracowanie metodologii oceny wpływu na środowisko takiego układu, szczególnie pod kątem optymalizacji, gdy
Identyfikacja uczestników i ich ról

Zdefiniowanie kategorii modelu biznesowego specyficznych wartości środowiskowych

\section{cja ucźw}

Role i działania udziałowców są niezbędne do tego, aby wspomóc zrealizowanie zidentyfikowanych propozycji wartości środowiskowych

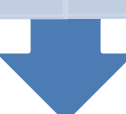

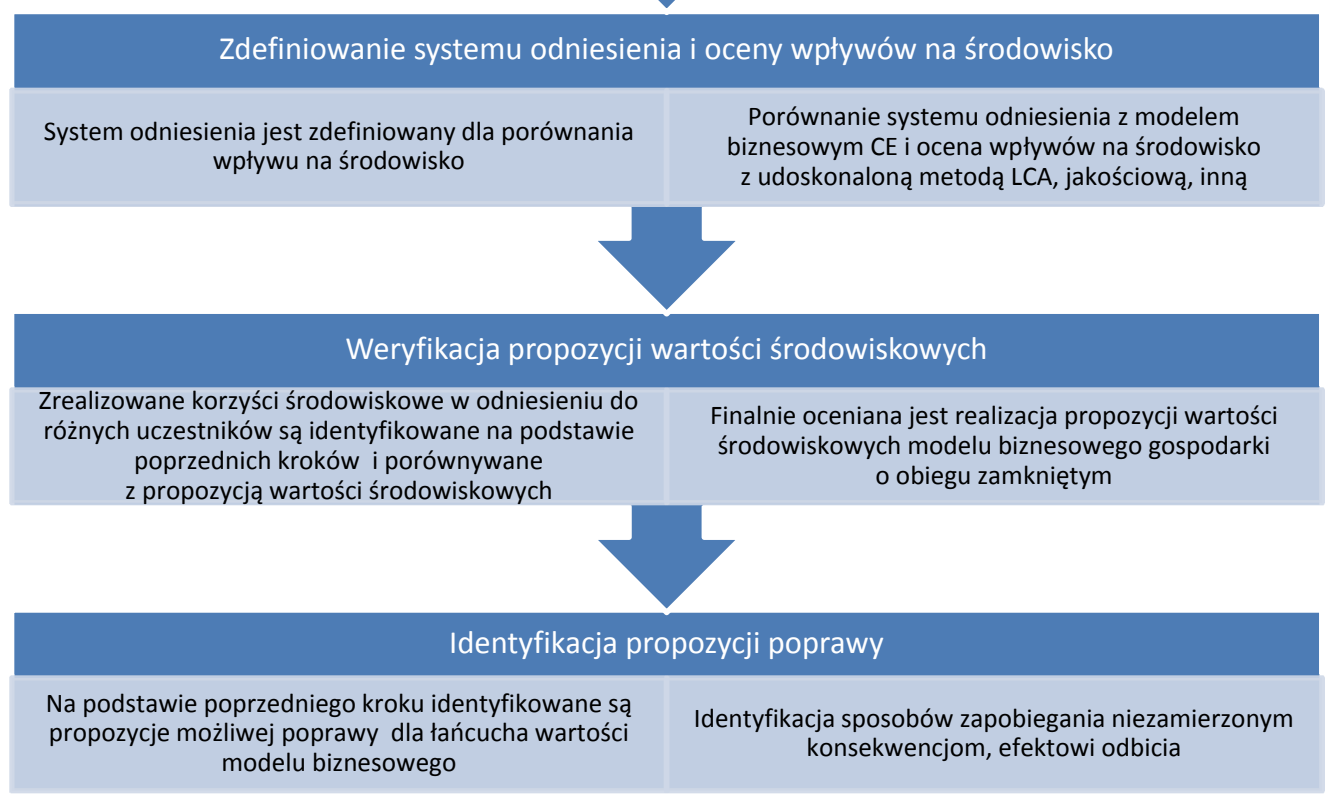

Rys. 2. Algorytm tworzenia ram modelu CE

Fig. 2. Algorithm of creating of model CE framework

możliwe są alternatywne zastosowania danego strumienia wewnątrz układu. Taki przypadek występuje, gdy wywar gorzelniany może stanowić jednocześnie nawóz na pola, zmniejszając zapotrzebowanie na nawozy mineralne i związaną z tym emisję GHG i wsad do biogazowni, gdzie produkowana jest energia elektryczna i cieplna.

Należy stwierdzić, że istotne jest także określenie funkcji celu i jednostki funkcjonalnej (Rogowska, 2017, 2018a). Do rozważenia są następujące scenariusze:

- funkcją celu jest minimalizacja kosztów przy założonym poziomie odzysku strumieni odpadowych;

- funkcją celu jest minimalizacja kosztów przy założonym poziomie redukcji negatywnego wpływu na środowisko (LCA);

- funkcją celu jest maksymalizacja odzysku strumieni odpadowych przy minimalizacji kosztów bądź minimalizacji negatywnego wpływu na środowisko naturalne. Jak wykazali w swojej pracy Lausselet et al. (2017), maksymalizacja odzysku surowców odpadowych nie jest jednoznaczna z minimalizacją emisji czynników szkodliwych do atmosfery; 
- funkcją celu jest minimalizacja emisji negatywnych czynników do atmosfery przy założonym stopniu odzysku strumieni odpadowych i/lub założonych kosztach;

- funkcją celu może być wyznaczenie zadanych wartości (stopnia odzysku strumieni odpadowych, emisji GHG, kosztów, innych) dla dwóch scenariuszy celem ich porównania.

Jednostka funkcjonalna jest ściśle powiązana z funkcją celu.

\section{Budowa modelu biznesowego gospodarki o obiegu zamkniętym dla FAME produkowanego $z$ alg}

Przyjęta modelowa ścieżka produkcji FAME z alg, przedstawiona na rysunku 1, obejmuje następujące główne elementy:

- oczyszczalnię ścieków;

- hodowlę alg;

- zbiórkę/suszenie alg;

- elektrociepłownię;

- ekstrakcję oleju;

- wytwórnię FAME;

- biogazownię;

- producenta pasz;

- producenta bionawozów.

\section{Zdefiniowanie granic systemu obliczeniowego}

Granice systemu obliczeniowego obejmują wymienione powyżej jednostki produkcyjne. Kluczowe jest zdefiniowanie momentu wejścia do systemu i momentu wyjścia. W przypadku modelu liniowego momentem wejścia jest wprowadzenie surowca na pierwszą instalację przetwarzającą, a momentem wyjścia ekspedycja gotowych produktów (INiG, 2017b).

Gospodarka o obiegu zamkniętym łączy ze sobą różne gałęzie przemysłu w taki sposób, aby wyjścia $\mathrm{z}$ jednych instalacji stanowiły wejścia na inne instalacje. Przy czym instalacje te dostarczają na rynek produkty o różnej wartości, a ich własna działalność generuje również negatywny wpływ na środowisko naturalne. Tak więc wejściami do modelu gospodarki o obiegu zamkniętym będą wszystkie zakupy, surowce, dostawy mediów z innych źródeł niż instalacje objęte systemem obliczeniowym. Wyjściami z systemu obliczeniowego będą wszystkie wyjścia z instalacji, które są kierowane do odbiorców zewnętrznych niewchodzących w skład systemu obliczeniowego oraz emisje (np. GHG) do środowiska naturalnego.

Włączenie danej instalacji do systemu obliczeniowego nie jest warunkowane umiejscowieniem jej w tej samej lokalizacji co pozostałe instalacje. Jednak w przypadku instalacji przyjmujących/

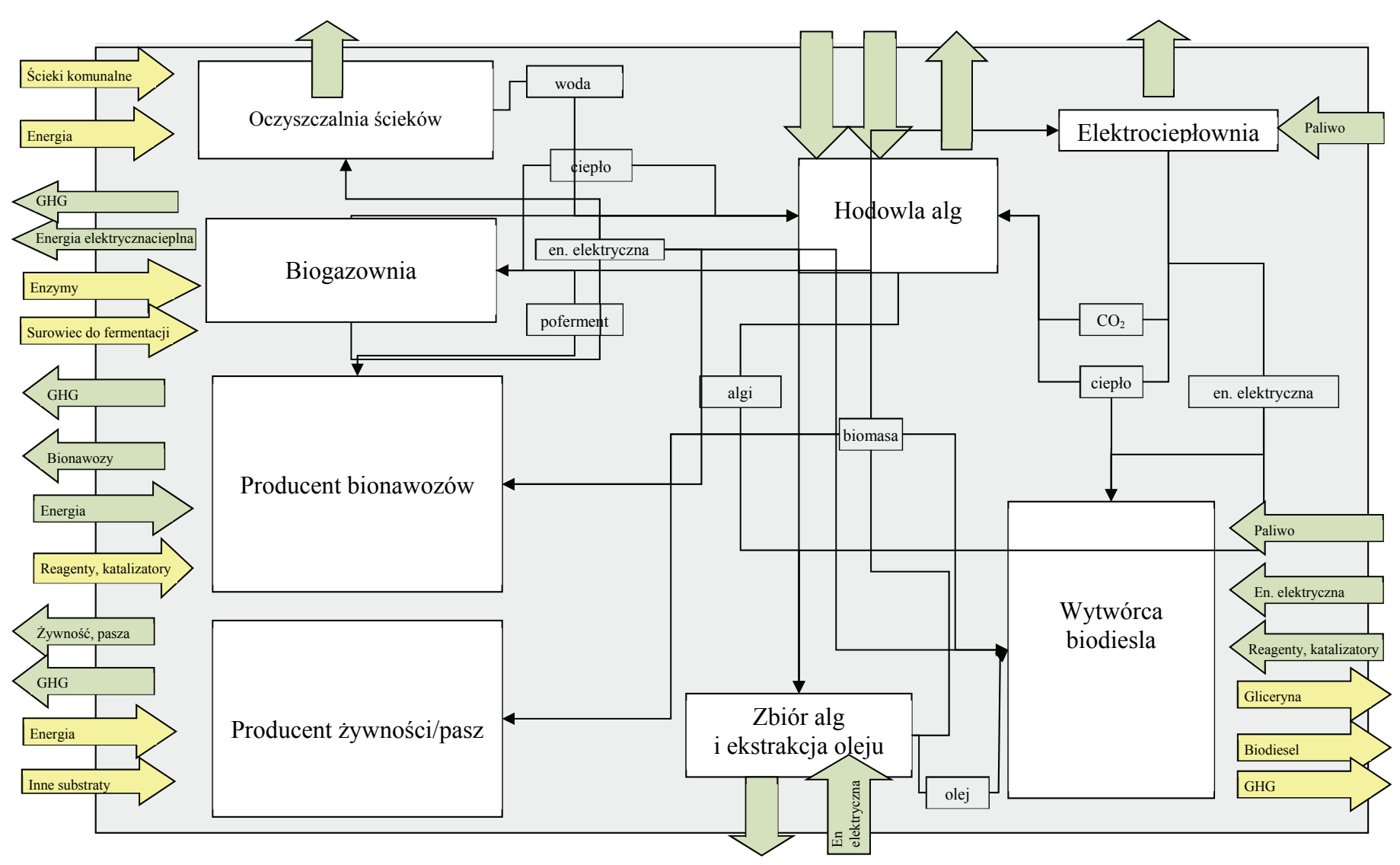

Rys. 3. Granice systemu obliczeniowego modelu CE dla produkcji FAME z alg (opracowanie własne)

Fig. 3. System boundaries of calculation system of CE model for algal FAME production (own work) 
wydających ciepło w parze lub takie strumienie, których przesył na odległość jest utrudniony (np. woda z oczyszczalni ścieków), jest to konieczne. W przypadku przesyłu innych strumieni (np. biomasa po ekstrakcji oleju) odbiorca zlokalizowany w dalszej odległości od jednostki produkcyjnej może być włączony do systemu, jednak trzeba w obliczeniach również uwzględnić transport, w szczególności emisję GHG z transportu.

Granice systemu obliczeniowego dla modelowej ścieżki produkcji FAME $\mathrm{z}$ alg w sposób schematyczny przedstawiono na rysunku 3.

Na rysunku 3 szarym polem oznaczono granice systemu obliczeniowego. Strzałki w kolorze żółtym oznaczają wejścia do systemu z zewnątrz, strzałki w kolorze zielonym to wyjścia z systemu. Cienkie czarne strzałki obrazują przepływy strumieni (masy i energii) wewnątrz systemu.

Model matematyczny będzie się składał z ośmiu jednostek przetwórczych (białe prostokąty na rysunku 3), gdzie wejścia mogą stanowić wejścia zewnętrzne (zielone strzałki) lub wyjścia z innych jednostek (wejścia wewnętrzne).

Zadaniem do zrealizowania przy budowie modelu jest opisanie równaniem matematycznym zależności pomiędzy jednostkami oraz zdefiniowanie funkcji celu.

Według schematu zaproponowanego przez Manninen et al. (2018) i przedstawionego na rysunku 2 pierwszym krokiem jest zdefiniowanie wartości środowiskowych. Przy liniowym podejściu do gospodarki jako wartość środowiskową definiuje się funkcję celu, którą może być minimalizacja emisji GHG wyrażonej w jednostce $\mathrm{gCO}_{2}$ eq/MJ FAME. Takie podejście można zaproponować również do analizowanego modelu. Jednak łańcuch dostaw FAME (cykl życia) nie obejmuje wszystkich elementów zdefiniowanego systemu obliczeniowego (rysunek 3) i istnieje ryzyko, że minimalizacja emisji GHG obejmująca tylko cykl życia FAME, poprzez brak połączenia z innymi elementami układu, spowodowałaby zwiększenie lub w ogóle nie nadzorowałaby emisji GHG generowanej przez inne instalacje. W klasycznym (liniowym) podejściu cykl życia obejmie uprawę alg, ekstrakcję oleju, biorafinerię i tylko emisje GHG generowane przez te instalacje są uwzględniane. Dlatego zdefiniowanie wartości środowiskowych powinno nastąpić dla całego układu. W tym przypadku taką wartość środowiskową stanowić może sumaryczna emisja GHG uwalniana poza układ, wyrażona w wartościach bezwzględnych $\mathrm{gCO}_{2} \mathrm{eq} /$ okres rozliczeniowy. Zdefiniowanych wartości środowiskowych może być więcej, jednak optymalizacja może być prowadzona tylko ze względu na jedną, w przypadku pozostałych należy przyjąć ograniczenia co do ich wartości.

W dalszej kolejności według Manninen et al. (2018) należy zdefiniować głównych uczestników i ich role. W przypadku modelowego schematu uczestnicy zostali przedstawieni na schemacie 3 wraz z powiązaniami pomiędzy nimi.
Kolejnym krokiem według publikacji Manninen et al. (2018) powinno być zdefiniowanie systemu odniesienia i zdefiniowanie wpływów środowiskowych. Systemem odniesienia może być ten sam układ przed wykonaniem optymalizacji. Budowa modelu i przeprowadzenie obliczeń oceny wpływu na środowisko dla ścieżki produkcji FAME $\mathrm{z}$ alg musi uwzględniać oddziaływanie na środowisko poszczególnych elementów układu i powiązań pomiędzy pojedynczymi instalacjami (elementami układu). Do tego należy opracować bilans masy i energii (Rogowska, 2017, 2018a), w układzie wejścia/wyjścia dla każdej instalacji, etykietując jednocześnie pochodzenie/przeznaczenie danego strumienia. Dodatkowo, dla rozwiązania postawionego zadania, każdy ze strumieni powinien być opisany cechą wpływu na środowisko, która jest optymalizowana. W przypadku redukcji emisji GHG można do tego wykorzystać poniższe równanie (INiG, 2017b):

$$
C_{x}=\varepsilon_{x} \cdot F_{e x}
$$

gdzie:

$C_{x}$ - jest wyrażoną w jednostkach masy ilością gazów cieplarnianych $\left(\mathrm{CO}_{2 \mathrm{eq}}\right)$ w zadanym czasie w wyniku zużycia danego strumienia wejściowego,

$\varepsilon_{x}$ - jest ilością danego strumienia masy lub energii zużytą w zadanym czasie,

$F_{e x}$ - jest wskaźnikiem emisji GHG dla danego strumienia, uwzględniającym jego wyprodukowanie i zużycie końcowe (wyrażony w jednostce $\mathrm{CO}_{2 e q} /$ jednostkę energii lub masy).

Przy czym emisja GHG liczona zgodnie z równaniem (1) powinna być wyznaczana tylko dla strumieni „opuszczających" układ (zaznaczonych żółtymi strzałkami na rysunku 3). Zmiana w układzie, poprzez np. skierowanie strumienia do innej jednostki wewnątrz układu, zwiększenie przerobu na jednej $z$ instalacji poprzez zdefiniowane powiązania pomiędzy instalacjami, będzie oddziaływała na cały układ powodując zmianę wartości funkcji celu.

Wtedy funkcja celu przybierze postać równania:

$$
\operatorname{Min}\left(\sum_{i=1}^{n} x_{i} \cdot F_{e i}\right)
$$

gdzie:

$x_{i}$ - ilość i-tego strumienia masy lub energii wychodzącego z układu,

$F_{e i}$ - wskaźnik emisji GHG dla i-tego strumienia wychodzącego z układu,

$n$ - liczba strumieni wychodzących z układu.

Funkcja celu rozwiązywana jest dla macierzy równań opisujących poszczególne zależności i ograniczenia jakościowe i ilościowe, np. wielkość produkcji pasz, moc biogazowni, które np. nie pozwalają na przyjęcie znacznej ilości surowca, 
będącego wyjściem z innych procesów. Dlatego dla każdego układu konieczne jest zdefiniowanie ograniczeń.

Układ przyjmie postać macierzy:

$$
\begin{array}{llll}
a_{11} \cdot x_{1} & +\ldots+ & a_{1 n} \cdot x_{n} & <b_{1} \\
a_{21} \cdot x_{1} & +\ldots .+ & a_{2 n} \cdot x_{n} & <b_{2} \\
\ldots . & +\ldots+ & \ldots & \ldots \\
a_{m 1} \cdot x_{1} & +\ldots .+A_{m n} \cdot x_{n} & <b_{m}
\end{array}
$$

gdzie

zmienne $x_{1}, x_{2}, \ldots, x_{n}-$ zmienne decyzyjne (np. ilość oleju $\mathrm{z}$ alg),

$a_{11}-a_{n m}-$ współczynniki parametry układu (np. wydajność procesu),

$b_{1}-b_{m}-$ warunki ograniczające (np. wielkość produkcji pasz).

Poszczególne równania w powyższej macierzy powinny być opisane zarówno dla strumieni wewnętrznych, jak i zewnętrznych.

Ostatnim elementem proponowanym w publikacji Manninen et al. (2018) jest zdefiniowanie propozycji poprawy. Do tego konieczne jest przeprowadzenie analizy danych poszczególnych składowych sumy z równania (2).

\section{Inwentaryzacja danych wejściowych i wyjściowych}

Przeprowadzenie obliczeń wpływu na środowisko wymaga sporządzenia bilansu masowego i energetycznego dla każdej instalacji wchodzącej w skład systemu obliczeniowego. Dotychczas przeprowadzany sposób opracowywania bilansu masowego (Rogowska i Jakóbiec, 2014; INiG, 2017a) został poniżej zmodyfikowany tak, aby mógł być zaaplikowany w modelu gospodarki o biegu okrężnym. A więc w szczególności do każdego strumienia dodano etykietę ,zewnętrzny”, ,wewnętrzny”.

Inwentaryzację danych wejściowych i wyjściowych przedstawiono w tabelach 1-8 dla poszczególnych instalacji produkcyjnych wchodzących w skład systemu. W niektórych przypadkach dany strumień może pochodzić zarówno z wewnątrz systemu, jak i z zewnątrz. Za przykład może posłużyć energia elektryczna, która może być nabywana z sieci elektroenergetycznej kraju lub z biogazowni będącej elementem układu. Wtedy taki strumień rozliczany jest jak dwa odrębne strumienie, ponieważ charakteryzuje się różnymi wskaźnikami emisji GHG; dla strumienia energii elektrycznej z biogazowni występują ograniczenia co do jego ilości, w przypadku energii z sieci z zewnątrz takich ograniczeń w praktyce nie ma.

Każdy zidentyfikowany w tabelach 1-8 strumień stanowi zmienną $x_{i} z$ równania (2) i macierzy (3) i powinien być wyrażony w jednostkach masy lub energii. Pozwoli to na opisanie zależności przepływów strumieni zarówno masy, jak i energii przez układ. Suma iloczynów wielkości strumieni i wskaźników emisji GHG dla każdego strumienia da informację odnośnie do przyjętej wartości środowiskowej, która może być optymalizowana (funkcja celu).

Opracowanie modelu według zaproponowanego schematu charakteryzuje się następującymi mocnymi stronami:

- elastyczność modelu: w przypadkach kilku instalacji strumienie wyjściowe z instalacji mogą znaleźć alternatywne zastosowanie na kilku innych instalacjach. Przykładem może być biomasa pozostała po ekstrakcji oleju z alg. Może być skierowana do elektrociepłowni jako biomasa lub jako surowiec do produkcji biogazu czy pasz. Jednocześnie każda z tych instalacji, oprócz biomasy z alg, posiada alternatywne zaopatrzenie w surowce. Zwiększenie produkcji oleju $\mathrm{z}$ alg nie stwarza problemu ekspedycji na zewnątrz modelu nadmiarowej biomasy $\mathrm{z}$ alg, co wiązałoby się z przypisaniem dodatkowej emisji GHG do rozpatrywanego układu;

- możliwość sprowadzenia (zakupu) strumieni z zewnątrz układu, jak i możliwość eksportu strumieni nadmiarowych na zewnątrz;

- możliwość dalszej rozbudowy modelu. Układ nie jest układem zamkniętym, można do niego włączać kolejne instalacje, np. gorzelnię fermentującą biomasę z alg po ekstrakcji oleju. Wtedy $\mathrm{CO}_{2}$ powstały w wyniku fermentacji mógłby być kierowany do hodowli alg. Jeśli natomiast ilość powstałego biogazu pokryłaby zapotrzebowanie energetyczne, wtedy można eliminować lub ograniczać działalność elektrociepłowni. Przy tak opisanym modelu cały układ można w łatwy sposób zbilansować i ocenić.

Natomiast do wad należą:

- w niewystarczający sposób opisane zależności ekonomiki poszczególnych procesów. W tym modelu dla oceny zyskowności przedsięwzięcia czy poszczególnych

Tabela 1. Dane wejściowe i wyjściowe dla oczyszczalni ścieków (Rogowska, 2018b)

Table 1. Input and output data for the sewage treatment plant

\begin{tabular}{|c|c|c|c|c|c|}
\hline \multicolumn{3}{|c|}{ Wejścia } & \multicolumn{2}{c|}{ Wyjścia } \\
\hline Nazwa strumienia & Etykieta & Instalacja pochodzenia & Nazwa strumienia & Etykieta & Instalacja docelowa \\
\hline \hline Energia elektryczna & zewnętrzne & - & woda & wewnętrzne & hodowla alg \\
\hline Energia elektryczna & wewnętrzne & biogazownia & emisja GHG & zewnętrzne & - \\
\hline Ścieki & zewnętrzne & - & & & \\
\hline
\end{tabular}


Tabela 2. Dane wejściowe i wyjściowe dla hodowli alg (Rogowska, 2018b)

Table 2. Input and output data for algae farm

\begin{tabular}{|c|c|c|c|c|c|}
\hline \multicolumn{3}{|c|}{ Wejścia } & \multicolumn{2}{c|}{ Wyjścia } \\
\hline Nazwa strumienia & Etykieta & Instalacja pochodzenia & Nazwa strumienia & Etykieta & Instalacja docelowa \\
\hline \hline Energia elektryczna & zewnętrzne & - & algi & wewnętrzne & zbiór alg i ekstrakcja oleju \\
\hline Energia elektryczna & wewnętrzne & biogazownia & emisja GHG & zewnętrzne & \\
\hline Ciepło & wewnętrzne & biogazownia & & & \\
\hline Ciepło & wewnętrzne & elektrociepłownia & & & \\
\hline Substancje odżywcze & zewnętrzne & - & & & \\
\hline
\end{tabular}

Tabela 3. Dane wejściowe i wyjściowe dla elektrociepłowni (Rogowska, 2018b)

Table 3. Input and output data for the power plant

\begin{tabular}{|c|c|c|c|c|c|}
\hline \multicolumn{3}{|c}{ Wejścia } & \multicolumn{2}{c|}{ Wyjścia } \\
\hline Nazwa strumienia & Etykieta & Instalacja pochodzenia & Nazwa strumienia & Etykieta & Instalacja docelowa \\
\hline \hline Paliwo & zewnętrzne & - & ciepło & wewnętrzne & hodowla alg \\
\hline Biomasa & wewnętrzne & zbiór alg i ekstrakcja oleju & ciepło & wewnętrzne & wytwórca biodiesla \\
\hline & & & energia elektryczna & zewnętrzne & - \\
\hline & & & energia elektryczna & wewnętrzne & wytwórca biodiesla \\
\hline & & & energia elektryczna & wewnętrzne & hodowla alg \\
\hline & & & $\mathrm{CO}_{2}$ & wewnętrzne & hodowla alg \\
\hline
\end{tabular}

Tabela 4. Dane wejściowe i wyjściowe dla wytwórcy biodiesla (Rogowska, 2018b)

Table 4. Input and output data for the biodiesel plant

\begin{tabular}{|c|c|c|c|c|c|}
\hline \multicolumn{3}{|c|}{ Wejścia } & \multicolumn{2}{c|}{ Wyjścia } \\
\hline Nazwa strumienia & Etykieta & Instalacja pochodzenia & Nazwa strumienia & Etykieta & Instalacja docelowa \\
\hline \hline Paliwo & zewnętrzne & - & biodiesel & zewnętrzne & zewnętrzne \\
\hline Biomasa & wewnętrzne & zbiór alg i ekstrakcja oleju & gliceryna & ze & - \\
\hline Olej & wewnętrzne & zbiór alg i ekstrakcja oleju & emisja GHG & zewnętrzne & - \\
\hline Ciepło & wewnętrzne & biogazownia & & & \\
\hline Ciepło & wewnętrzne & elektrociepłownia & & & \\
\hline Reagenty, katalizatory & zewnętrzne & - & & & \\
\hline Energia elektryczna & wewnętrzne & biogazownia & & & \\
\hline Energia elektryczna & zewnętrzne & - & & & \\
\hline
\end{tabular}

Tabela 5. Dane wejściowe i wyjściowe dla zbioru alg i ekstrakcji oleju (Rogowska, 2018b)

Table 5. Input and output data for algae harvesting and oil extraction

\begin{tabular}{|c|c|c|c|c|c|}
\hline \multicolumn{3}{|c|}{ Wejścia } & & Wyjścia \\
\hline Nazwa strumienia & Etykieta & Instalacja pochodzenia & Nazwa strumienia & Etykieta & Instalacja docelowa \\
\hline \hline Algi z hodowli & wewnętrzne & hodowla alg & olej & wewnętrzne & wytwórca biodiesla \\
\hline Energia elektryczna & wewnętrzne & biogazownia & biomasa & wewnętrzne & wytwórca biodiesla \\
\hline Energia elektryczna & zewnętrzne & - & biomasa & wewnętrzne & elektrociepłownia \\
\hline & & & biomasa & wewnętrzne & biogazownia \\
\hline & & & biomasa & wewnętrzne & producent bionawozów \\
\hline & & & biomasa & wewnętrzne & producent żywności/pasz \\
\hline & & & emisja GHG & zewnętrzne & - \\
\hline
\end{tabular}


Tabela 6. Dane wejściowe i wyjściowe dla biogazowni (Rogowska, 2018b)

Table 6. Input and output data for the biogas plant

\begin{tabular}{|c|c|c|c|c|c|}
\hline \multicolumn{3}{|c|}{ Wejścia } & \multicolumn{3}{|c|}{ Wyjścia } \\
\hline Nazwa strumienia & Etykieta & Instalacja pochodzenia & Nazwa strumienia & Etykieta & Instalacja docelowa \\
\hline Enzymy & zewnętrzne & - & energia elektryczna & wewnętrzne & hodowla alg \\
\hline $\begin{array}{c}\text { Surowiec } \\
\text { do biogazowni }\end{array}$ & zewnętrzne & - & energia elektryczna & wewnętrzne & zbiór alg i oleju \\
\hline \multirow[t]{7}{*}{ Biomasa } & wewnętrzne & zbiór alg i ekstrakcja oleju & energia elektryczna & wewnętrzne & wytwórca biodiesla \\
\hline & & & energia elektryczna & wewnętrzne & oczyszczalnia ścieków \\
\hline & & & energia elektryczna & zewnętrzne & - \\
\hline & & & ciepło & wewnętrzne & hodowla alg \\
\hline & & & ciepło & wewnętrzne & wytwórca biodiesla \\
\hline & & & emisja GHG & zewnętrzne & - \\
\hline & & & proferment & wewnętrzne & producent bionawozów \\
\hline
\end{tabular}

Tabela 7. Dane wejściowe i wyjściowe dla producenta bionawozów (Rogowska, 2018b)

Table 7. Input and output data for the bio-fertilizer producer

\begin{tabular}{|c|c|c|c|c|c|}
\hline \multicolumn{3}{|c|}{ Wejścia } & \multicolumn{2}{c|}{ Wyjścia } \\
\hline Nazwa strumienia & Etykieta & Instalacja pochodzenia & Nazwa strumienia & Etykieta & Instalacja docelowa \\
\hline \hline Proferment & wewnętrzne & biogazownia & bionawozy & zewnętrzne & - \\
\hline Biomasa & wewnętrzne & zbiór alg i ekstrakcja oleju & emisja GHG & zewnętrzne & - \\
\hline $\begin{array}{c}\text { Reagenty, } \\
\text { współsubstraty }\end{array}$ & zewnętrzne & - & & & \\
\hline Energia elektryczna & zewnętrzne & - & & & \\
\hline Energia elektryczna & wewnętrzne & elektrociepłownia & & & \\
\hline Energia elektryczna & wewnętrzne & biogazownia & & & \\
\hline
\end{tabular}

Tabela 8. Dane wejściowe i wyjściowe dla producenta żywności/pasz (Rogowska, 2018b)

Table 8. Input and output data for the food/feed producer

\begin{tabular}{|c|c|c|c|c|c|}
\hline \multicolumn{3}{|c|}{ Wejścia } & \multicolumn{2}{c|}{ Wyjścia } \\
\hline Nazwa strumienia & Etykieta & Instalacja pochodzenia & Nazwa strumienia & Etykieta & Instalacja docelowa \\
\hline \hline Biomasa & wewnętrzne & zbiór alg i ekstrakcja oleju & emisja GHG & zewnętrzne & - \\
\hline $\begin{array}{c}\text { Reagenty, } \\
\text { współsubstraty }\end{array}$ & zewnętrzne & - & żywność/pasze & zewnętrzne & - \\
\hline Energia elektryczna & zewnętrzne & - & & & \\
\hline
\end{tabular}

niezależnych jednostek wchodzących w skład układu można jedynie do poszczególnych strumieni przypisać koszt (analogicznie jak wskaźnik emisji GHG). Jeśli koszt zależny będzie od skali produkcji (a tak jest w większości przypadków), to opracowany model nie pozwala na wprowadzenie zależności kosztu jednostkowego od wielkości przerobu. Wtedy rozwiązanie optymalne, w którym jedna z instalacji charakteryzowałaby się dużo większą skalą produkcji w porównaniu do stanu wyjściowego, ze względu na ekonomikę byłoby błędnie oszacowane;

- nieliniowość układu. Występujące pętle i zawroty strumieni, nawet pośrednie, sprawiają, że układ jest nieliniowy. Dla takiego układu trudno jest dobrać narzędzia informatyczne, które mogłyby przeprowadzić obliczenia.

\section{Podsumowanie}

Budowa modelu biznesowego dla gospodarki o obiegu zamkniętym jest zagadnieniem stosunkowo nowym. Do budowy takiego modelu adaptowane są modele ekonomiczne czy społeczne. Modele te jednak nakierunkowane są na zysk przedsiębiorstwa, podczas gdy w gospodarce CE zysk rozumiany jako efekt tylko i wyłącznie finansowy nie jest najistotniejszy. Stąd w modelach 
CBE istnieje konieczność zdefiniowania wartości środowiskowych, a pojęcie zysku przedsiębiorstwa uwzględnia realizację tych wartości. Kolejnym etapem powinno być opracowanie odpowiednich uwarunkowań rynkowych, tak aby zachęcić przedsiębiorców do takich zachowań rynkowych (zakupy surowców, sprzedaż produktów), aby w układzie gospodarki CE osiągnąć jak najkorzystniejsze wartości środowiskowe.

Artykuł powstał na podstawie pracy statutowej pt.: Produkcja FAME z alg jako element circular economy - praca INiG - PIB na zlecenie MNiSW; nr zlecenia: 0078/TP/18, nr archiwalny: DK-4100-78/18.

\section{Literatura}

Adeniyi O.M., Azimov U., Burluka A., 2018. Algae biofuel: Current status and future applications. Renewable and Sustainable Energy Reviews, 90: 316-335.

Berdechowski K., 2017. Analiza składowych emisji GHG z upraw rzepaku wykorzystywanego do produkcji estrów metylowych kwasów tłuszczowych. Nafta-Gaz, 5: 360-364. DOI: 10.18668/ NG.2017.05.08.

Boons F., Lüdeke-Freund F., 2013. Business models for sustainable innovation: state-of-the-art and steps towards a research agenda. Journal of Cleaner Production, 45: 9-19.

Bourguignon D., 2014. Turning waste into a resource. $<$ http://www. europarl.europa.eu/RegData/etudes/BRIE/2014/545704/EPRS BRI(2014)545704_REV1_EN.pdf> (dostęp: listopad 2018).

D'Amato D., Droste N., Allen B., Kettunen M., Lähtinen K., Korhonen J., Leskinen P., Matthies B.D., Toppinen A., 2017. Green, circular, bio economy: A comparative analysis of sustainability Avenues. Journal of Cleaner Production, 168: 716-734.

Galvao G.D.A., de Nadae J., Clemente D.H., Chinen G., de Carvahlo M.M., 2018. Circular economy: Overview of Barriers. $10^{\text {th }}$ CIRP Conference on Industrial Product-Service Systems, IPS2 2018, 29-31.05.2018, Linköping, Sweden. Procedia CIRP 73, 79-85.

Geissdoerfer M., Morioka S.N., de Carvalho M.M, Evans S., 2018. Business models and supply chains for the circular economy. Journal of Cleaner Production, 190: 712-721.

Hasnain S.S., Ahmed I.R., Rizwan M., Mahmood N., Shah F.A., Pervez A., 2018. Potential of microalgal biodiesel production and its sustainability perspectives in Pakistan. Renewable and Sustainable Energy Reviews, 81: 76-92.

INiG, 2017a. System KZR INiG/7: System certyfikacji zrównoważonej produkcji biopaliw i biopłynów: Wytyczne w zakresie sposobu prowadzenia systemu bilansu masy. <http://www.kzr.inig. eu/file/repository/system_kzr_inig_7_pl_wyd._3.pdf $>$ (dostęp: listopad 2018).

INiG, 2017b. System KZR INiG/8: System certyfikacji zrównoważonej produkcji biopaliw i biopłynów: Wytyczne w zakresie sposobu wyznaczania jednostkowych wartości emisji GHG dla biopaliw, biopłynów w cyklu życia. <http://www.kzr.inig.eu/file/repository/system_kzr_inig_8_pl_wyd.3.pdf> (dostęp: listopad 2018).

Lausselet C., Cherubini F., Oreggioni G.D., del Alamo Serrano G., Becidan M., Hu X., Rørstad P.Kr., Strømman A.H., 2017. Norwegian Waste-to-Energy: Climate change, circular economy and carbon capture and storage. Resources, Conservation \& Recycling, 126: 50-61.

Lindahl M., Sundin E., Sakao T., 2014. Environmental and economic benefits of Integrated Product Service Offerings quantified with real business cases. Journal of Cleaner Production, 64: 288-296.
Manninen K., Koskela S., Antikainen R., Bocken N., Dahlbo H., Aminoff A., 2018. Do circular economy business models capture intended environmental value propositions? Journal of Cleaner Production, 171: 413-422.

Pratap M., Arpita S., Roy M., 2018. Developing an extended theory of planned behavior model to explore circular economy readiness in manufacturing MSMEs, India. Resources, Conservation \& Recycling, 135: 313-322.

Rastogi R.P., Pandey A., Larroche Ch., Madamwar D., 2018. Algal Green Energy - R \& D and technological perspectives for biodiesel production. Renewable and Sustainable Energy Reviews, 82: 2946-2969.

Rogowska D., 2017. Opracowanie założeń do wdrożenia idei „circular economy" w produkcji biopaliw. Dokumentacja INiG - PIB. Numer archiwalny: DK-4100-103/17.

Rogowska D., 2018a. Produkcja biopaliw jako element gospodarki o obiegu zamkniętym. Nafta-Gaz, 2: 156-163. DOI: 10.18668/ NG.2018.02.10.

Rogowska D., 2018b. Produkcja FAME z alg jako element „circular economy". Dokumentacja INiG - PIB. Numer archiwalny: DK-4100-78/18.

Rogowska D., Jakóbiec J., 2014. Emisja GHG w cyklu życia paliw silnikowych. Część I - wytyczne do konstruowania bilansu masowego produkcji. Nafta-Gaz, 9: 639-646.

\section{Akty prawne i normatywne}

Dyrektywa Parlamentu Europejskiego i Rady (UE) 2015/1513 z dnia 9 września 2015 r. zmieniająca dyrektywę 98/70/WE odnoszącą się do jakości benzyny i olejów napędowych oraz zmieniająca dyrektywę 2009/28/WE w sprawie promowania stosowania energii ze źródeł odnawialnych (Dz.Urz. UE L 239).

Dyrektywa Parlamentu Europejskiego i Rady 2009/28/WE z dnia 23 kwietnia 2009 r. w sprawie promowania stosowania energii ze źródeł odnawialnych zmieniająca i w następstwie uchylająca dyrektywy 2001/77/WE oraz 2003/30/WE (Dz.Urz. UE L $140 / 16$ z 9.06 .2009$)$.

EEA, 2016. Circular Economy in Europe. Developing the Knowledge Base. EEA Report No 2/2016.

European Parliament legislative resolution of 13 November 2018 on the proposal for a directive of the European Parliament and of the Council on the promotion of the use of energy from renewable sources (recast) (COM(2016)0767 - C8-0500/2016 - 2016/0382(COD)) (Ordinary legislative procedure - recast). $<$ http://www.europarl.europa.eu/sides/getDoc.do?pubRef=-// $\mathrm{EP} / / \mathrm{TEXT}+\mathrm{TA}+\mathrm{P} 8-\mathrm{TA}-2018-0444+0+\mathrm{DOC}+\mathrm{XML}+\mathrm{V} 0 / /$ EN\&language $=$ EN\#BKMD-8 $>$.

Komunikat Komisji do Parlamentu Europejskiego, Rady, Europejskiego Komitetu Ekonomiczno-Społecznego i Komitetu Regionów Ku gospodarce o obiegu zamkniętym: program ,zero odpadów" dla Europy. COM/2014/0398 final. <http://eur-lex.europa.eu/legal-content/PL/TXT/?uri=CELEX:52014DC0398> (dostęp: listopad 2018).

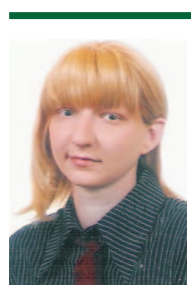

Mgr inż. Delfina ROGOWSKA

Starszy specjalista badawczo-techniczny; zastępca kierownika Zakładu Paliw i Procesów Katalitycznych. Biuro Systemów Certyfikacji Biomasy

Instytut Nafty i Gazu - Państwowy Instytut Badawczy ul. Lubicz 25 A, 31-503 Kraków

E-mail: delfina.rogowska@inig.pl 